\title{
Modern Trends in the Development of Renewable Energy: the Experience of the EU and Leading Countries of the World*,**
}

\author{
Leonid Hr. MelnyK ${ }^{i}$, Oleksandr M. DeryKolenko ${ }^{i i}$, Yuriy O. Mazin ${ }^{i i i}$, \\ Olena I. Matsenko ${ }^{i v}$, Vladyslav S. Piven $v$
}

Energy security and independence is one of the key points in sustainable development. In modern conditions of rapid growth and development of technologies, more and more attention is paid to finding practical solutions for environmentally friendly and inexpensive energy production. For a long time, scientists from various fields of scientific activity around the world have been engaged in the development and use of alternative energy sources. The share of renewable energy sources in the generation of electricity around the world is growing steadily, which indicates an increase in the use of energy obtained from alternative sources, such as, for example, wind and sun. These trends testify to the desire of consumers to abandon the use of fossil energy sources and nuclear power plants as much as possible in order to ensure further sister development. Under the current conditions of the COVID-19 pandemic, the demand for electricity worldwide has decreased, however, as the study shows, this pandemic has not affected the development of renewable energy. The article analyzes modern trends in the development of renewable energy, taking into account the experience of the EU countries and leading countries of the world in this area. As a result, it was concluded that in modern conditions, to achieve sustainable development, transformation processes are needed in such an important area as energy. Various processes in the global economy, which contributed to the intensive development of alternative energy sources, served as a powerful impetus for such changes. Many countries have made significant progress in the development of renewable energy.

Keywords: trend, renewable energy sources, electricity, development, renewable energy, alternative energy, energy security.

УДК: 330.35:620.9(4-6СС)

JEL Codes: Q40

Introduction. Energy is needed to ensure almost all aspects of human well-being. In recent decades, the world community has been concerned about the negative impact of

${ }^{i}$ Leonid Hr. Melnyk, D.Sc. (Economics), Professor, Professor of Department of Economics, Entrepreneurship and Business-Administration, Director of Research Institute for Development Economics (IDE) at Sumy State University;

ii Oleksandr M. Derykolenko, D.Sc. (Economics), Associate Professor of the Department of Economics, Entrepreneurship and Business Administration, Sumy State University;

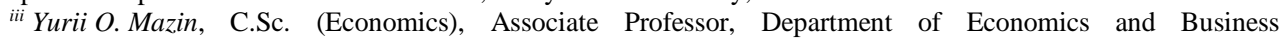
Administration, Sumy State University;

iv Olena I. Matsenko, Technician of the 1st Category of the Research Part of the Department of Economics, Entrepreneurship and Business Administration, Sumy State University;

${ }^{v}$ Vladyslav S. Piven, Student of the Oleg Balatskyi Academic and Research Institute of Finance, Economics and Management, Sumy State University.

${ }^{*}$ The publication contains the results of research conducted within the framework of the scientific research work "Development of the Fundamental Bases of the Reproductive Mechanism of Socio-Economic Development during the Third Industrial Revolution" (No 0118U003578).

${ }^{* *}$ The publication contains the results of research of European Commission grants "Jean Monnet Chair in EU Economic Policies and Civil Society" (619878-EPP-1-2020-1-UA-EPPJMO-CHAIR) and EU legislative, economic and social transition to sustainable society within Industry 4.0 and 5.0 (619997-EPP-1-2020-1-UA-EPPJMO-CHAIR).

(C) L. Hr. Melnyk, O. N. Derykolenko, Yu. O. Mazin, O. I. Matsenko, V. S. Piven, 2020.

https://doi.org/10.21272/mer.2020.89.09

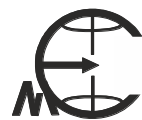


traditional energy sources on the environment and the search for their solution. In June 2007, the EU Parliament adopted the infrastructure development plan developed by D. Rifkin. This plan is intended to address three issues, namely: the global economic crisis, energy security and climate change. According to D. Rifkin, the interaction of the five basic principles of the Third Industrial Revolution will create a new super-technological platform for the development of a new economic era. These principles are directly related to the transformation of the energy sector. The first principle is the development of renewable energy sources.

Purpose of the article. The purpose of this article is to review, analyze and systematize modern trends in the development of renewable energy. The study of the environmental and economic drivers of the development of renewable energy allows us to understand the prerequisites and the need for transformation processes in the energy sector. A detailed analysis of trends in the development of alternative energy in the world makes it possible to trace promising directions in different countries and get acquainted with their experience, as well as highlight the main strategic directions in the development of renewable energy.

\section{Results of the research.}

\section{Environmental and economic drivers of renewable energy development}

Renewable energy sources have many undeniable advantages. First of all, they are much more environmentally friendly than traditional methods of generating energy based on the combustion of fossil fuels. However, besides, they have some undoubted qualities that distinguish them favorably from representatives of traditional energy.

First, renewable energy sources are characterized by stability and relative inexhaustibility, which allows them to provide a stable mode of operation of energy systems, and with them, the entire economy. The work of the sun and wind is characterized by stable regularity. There are already technical solutions that ensure the operation of wind farms at minimum wind speed and even complete calm. An even more stable source is geothermal heat. In combination with efficient means of accumulating and storing energy, these sources provide a stable mode of operation of the power system both in terms of energy supply and in terms of the price for the generated energy. This makes it possible to establish a stable regulation procedure (diversification of selling prices depending on the time of day and seasonality of consumption).

It is no coincidence that the period of adoption of the five mentioned principles for the implementation of Third industrial revolution coincided with the 2007 energy crisis when the price of oil on world markets jumped from an average of several dozen to $\$ 120$ per barrel. The economies of the leading countries of the world reacted to this with a sharp jump in prices for manufactured goods and a slowdown in their activity. When, in July 2008, the price for a barrel of oil jumped to \$ 147 and the prices of manufactured goods soared up along the entire chain, doubling and tripling for some groups of goods. Due to a sharp decline in the purchasing power of the population, the world's leading economies have practically stopped completely. Two months later, a severe financial crisis erupted.

The natural reaction of economic systems to the energy crisis was a significant decrease in their activity. As a result, in 2009 oil prices dropped to $\$ 30$ per barrel. Cheaper oil prices spurred economic activity, which in turn, over time, motivated an increase in oil prices. And by 2012, it again reached the $\$ 120$ mark. The prices of other goods also followed them up. Two years later, the pendulum swung in the opposite direction, bringing oil prices to $\$ 30$. And the economy again went into a "vicious" vicious circle.

As we can see, the very nature of energy based on the combustion of fossil fuels determines an unstable behavior of economic systems. Renewable energy can overcome these 
Leonid Hr. Melnyk, Oleksandr M. Derykolenko, Yuriy O. Mazin, Olena I. Matsenko, Vladyslav S. Piven. Modern Trends in the Development of Renewable Energy: the Experience of the EU and Leading Countries of the World

problems. With its sufficiently developed infrastructure (accumulation systems, "smart" power distribution networks, etc.), it can quite easily not only ensure a stable regime of electricity supply but also cope with the problems of significant fluctuations in energy consumption during daily and weekly periods. As you know, this creates quite serious difficulties for traditional energy.

Another distinguishing feature of renewable energy sources is their relative efficiency. It is because the cost indicators of the production of alternative energy have one remarkable feature. In its cost, there are practically no (or close to zero) variable costs. This is true for most types of renewable energy, with the exception, perhaps, of biogas.

Economists know that variable costs are those types of costs that respond to changes in the volume of production. For example, for traditional power engineering (be it a thermal or nuclear power plant), the operating costs of production grow with the growth of the volume of electricity produced. Indeed, with each $\mathrm{kWh}$ of electricity produced, you have to pay more for the purchase of fuel and human labor that ensures the production process.

Solar, wind, or geothermal generators do not need fuel. The sources of their work are the forces of nature free of charge. Yes, and human labor during their work has nothing to do with the amount of energy produced. It is mainly aimed at troubleshooting possible problems. Except for the initial costs (investments) for the installation of the generator, the generation of electricity or heat itself is free.

As you can see, "green" energy (solar, wind, geothermal heat, tidal energy) allows you to do without fuel and the chemical processes of its combustion. This means that entire industry links are excluded from production cycles, which provide: the extraction of mineral resources; reclamation of disturbed landscapes; transportation of raw materials (wagons/bulk carriers - in the case of coal or tanks/pipelines/tankers - in the case of oil and gas); fuel combustion in power plants; manufacturing of cleaning equipment and waste disposal. The processes of creating machine-building and construction enterprises are also excluded, where capacities are formed for the implementation of all the mentioned processes. Although, of course, one should not forget that the creation of the installations themselves for generating renewable energy cannot do without significant costs. It should also be remembered about the costs that will be needed for the disposal of alternative energy generators when they will run out of terms of their work. However, with significant amounts of used generators, this work can be put on stream. This will be greatly facilitated if the processes of disassembly and disposal of generators are provided for constructively during the design of the generators themselves.

In any case, the irrefutable fact remains that solar and wind energy provide energy production with minimal labor costs at the stage of their operation. American economist J. Rifkin called this phenomenon "zero variable cost" energy. Besides, compared with carbon and nuclear energy, the operation of renewable energy sources practically eliminates the costs materialized in the extraction and processing of initial energy carriers [1].

At the turn of 2016-2017, the average cost of producing alternative energy in some countries equaled similar indicators for traditional energy. By 2020, a similar parity had already been achieved at the level of the world average [2,3].

The United States Energy Information Administration (EIA) has fulfilled the forecast of unit costs for the production of $1 \mathrm{MWh}$ of electricity for the period until 2022 for various energy sources, provided that it will be obtained from newly built facilities. The forecast took into account the dynamics (over 30 years) of the given indicators of the total cost (LCOE) over the entire production cycle (Table 1$)$. 
Л. Г. Мельник, О. М. Дериколенко, Ю. О. Мазін, О. І. Маценко, В. С. Півень.

Сучасні тренди розвитку відновлюваної енергетики: досвід ЄС та провідних країн світу

Table 1

Indicators of the reduced unit average global costs of energy production from various sources [4]

\begin{tabular}{|l|c|}
\hline \multicolumn{1}{|c|}{ Production capacity type } & $\begin{array}{c}\text { Total present value, USD / MWh (USD / } \\
\text { MWh) }\end{array}$ \\
\hline Offshore wind farm & 138.0 \\
\hline Coal e / s with 30\% residual CO2 content & 130.1 \\
\hline Coal fired e / s with 90\% residual CO2 content & 119.1 \\
\hline Biomass power plants & 95.3 \\
\hline Modern nuclear power plants & 92.6 \\
\hline Gas e / s (with CO2 capture) & 74.9 \\
\hline Photovoltaic (Pv) SES & 63.2 \\
\hline HPP & 61.7 \\
\hline Ground wind power plants & 59.1 \\
\hline Gas e / s (without CO2 capture) & 50.1 \\
\hline Geothermal power & 44.6 \\
\hline
\end{tabular}

It should be borne in mind that, due to technological progress, unit costs per unit of installed capacity in alternative energy will rapidly decline. For example, it is expected that from 2016 to 2018 alone, the cost of producing a unit of solar energy should be reduced by almost $50 \%$, and wind energy - by almost $35 \%[4,5,6]$. And this is with non-decreasing renewable energy sources.

A completely different perspective is seen for traditional energy. Its technical basis is already at the limit of improvement and improvement of specific economic indicators, while the natural conditions for the extraction of fossil fuels are constantly deteriorating due to the depletion of reserves of natural raw materials. The "shale revolution" can only slow down the process of the objective rise in the cost of traditional energy. It is impossible to stop it.

Another advantage of renewable energy sources is their distribution. Unlike traditional energy fuel sources that units possess, renewable energy sources are available to most of the world's inhabitants. Moreover, this applies not only to the ubiquitous physical presence of the energy sources themselves (sun, wind, geothermal heat) but also to the economic possibilities of energy generation itself. Already today, many homeowners can afford to have their power plants to meet their electricity needs. Tomorrow it will be available to millions, and the day after tomorrow - to billions of the inhabitants of the Earth.

One of the ideologists of the implementation of the Third industrial revolution in Europe J. Rifkin in his works has repeatedly emphasized the need for the systematic implementation of all five directions (principles) mentioned at the beginning of this subsection. The implementation of any of them in isolation from the others significantly reduces the effectiveness of the measures being taken.

\section{Trends in the development of global alternative energy}

The fact that alternative energy has long since passed from plans existing on paper into reality is convincingly evidenced by numerous figures and facts.

The ways of sustainization of the energy sector are associated with three main areas of energy use: 1) electricity generation; 2) heating and cooling of premises; 3) driving vehicles. The increase in the share of renewable energy in each of these areas is associated with the solution of complex technical problems that are of a systemic nature. In particular, the first direction is associated with the development of technical means for generating electricity and systems for long-term storage (accumulation) of energy. The second direction requires the 
Leonid Hr. Melnyk, Oleksandr M. Derykolenko, Yuriy O. Mazin, Olena I. Matsenko, Vladyslav S. Piven. Modern Trends in the Development of Renewable Energy: the Experience of the EU and Leading Countries of the World

solution of a complex of engineering, architectural, and urban planning problems. The third direction determines the development of engineering solutions for electrification and hydrogenization of transport.

As an example, we can mention the indicators of the share of renewable energy in these three areas in Sweden, which is the leader in sisterhood policy among European countries. In 2017, the total share of renewable energy in the total energy balance of the country was $55 \%$, including $69 \%-$ in the processes of heating and cooling premises, $66 \%$ - in electricity generation; $27 \%$ - in transport [7].

According to the International Energy Agency, about $70 \%$ of all new generation in the next 5 years will come from renewable sources. Their total share in world electricity production will grow from $25.0 \%$ to $29.4 \%$ (including hydro generation), and in heat production for heating - from $10.8 \%$ to $11.0 \%$ [8].

The authors of the report note a rapid leap forward in India, which increased the share of solar and wind generation from $3 \%$ in 2015 to $10 \%$ in 2020 [9, 10]. In the US and the EU, the share of coal-fired generation fell by $31 \%$ and $32 \%$ over five years, respectively [11]. On our behalf, we add that even more significant success has been achieved by the alternative energy industry of Ukraine, which has increased its share in electricity generation over five years from $1.5 \%$ in 2015 to $8.6 \%$ in 2020 .

The EU has achieved significant success, setting itself the ambitious goal of increasing the share of generation. In fact, only wind and solar-generated $21 \%$ of electricity generation in 2020 [10]. In total, in the EU, taking into account hydropower, the share of renewable energy sources increased to $40 \%$ in 2020 , exceeding the share of electricity generation based on fossil fuels (coal, gas, oil), which in 2020 was only 34\% [12]. In some countries (Austria, Germany, Great Britain, Norway, Portugal, Switzerland, Sweden) the results are even more impressive.

Germany. Over the year, Germany was able to increase the share of renewable sources in electricity production from $44.4 \%$ in 2019 to almost $52 \%$ (51.9 \%) in 2020. The structure of "green" electricity is: onshore wind farms $-28.9 \%$; biomass energy $-7.7 \%$; offshore wind farms $-6.2 \%$; solar energy $-5.0 \%$; hydropower $-3.1 \%$; waste $-1.0 \%$, an insignificant fraction of a percent is geothermal heat [13]. As you can see, the country's "green" energy was able to step over the half of the energy balance. At the same time, alternative energy has increased its share over the year by almost $14 \%$. Nuclear power plants and coal-fired power engineering reduced their contribution by 18 and $44 \%$, respectively (ibid.).

Great Britain. In 2020, renewable energy in Britain has set a number of records. The share of electricity generation from renewable energy sources has reached $47 \%$, close to half of the energy balance. The structure of this contribution of renewable energy is as follows: land-based wind farms $-14.0 \%$; SES $-13.0 \%$; offshore wind farms $-10.0 \%$; bioenergy $-8.0 \%$; HPP $-2.0 \%$. If we add to this the share of nuclear power plants, then the total contribution of low-carbon energy rises to $62 \%$. At the same time, the share of fossil fuel energy for the first time in history fell below $40 \%$ and amounted to only $35.4 \%[14,15]$.

Portugal. The production of electricity from renewable sources in the country at the beginning of 2020 reached $51 \%$, including $27 \%$ of energy production was provided by wind generators. The rest was distributed between solar energy (13\%) and hydropower (11\%). In December 2019, due to the traditional reduction in energy consumption for the Christmas holidays, the share of renewable energy sources in general increased to $76 \%$, while the share of traditional fuel energy accounted for $24 \%$ (surplus energy was exported to Spain [16].

Switzerland. The country is implementing a policy of constant greening of the energy sector, including through a reduction in the share of nuclear energy. In particular, in 2018 the share of energy consumption from renewable sources reached $68 \%$ (a year earlier $-62 \%$ ). At the same time, 
the share of nuclear energy in power generation decreased from $17 \%$ to $15 \%$. The largest contribution to electricity generation is provided by hydroelectric power plants $-60.5 \%$; the share of sun, wind, and biomass accounts for $7.2 \%$ (a year earlier $-5.9 \%$ ), another $1 \%$ comes from waste incineration and biofuel [17].

Austria. The country is successfully solving the task set by the EU: to reach the level of $34 \%$ of the share of renewable sources in total energy consumption by 2020 . At the same time, $10 \%$ of energy carriers in transport are from renewable sources. The share of renewable sources in the production of electricity exceeds $80 \%$, including $60 \%$ from hydroelectric power plants. By 2030 , the share of hydropower is planned to increase to $85 \%$ [18].

Norway. The country is one of the most advanced in the field of greening the energy sector. The use of renewable resources is characterized by the following figures. The share of renewable energy sources is: in the total energy consumption $-69.4 \%$, in heating and cooling $-43.0 \%$, in power generation $-114 \%$; in transport $-10 \%$. In all likelihood, one should comment on the indicator of the share of RES in electricity production. A figure exceeding $100 \%$ means a significant export of generated energy, which is entirely from renewable sources. If we consider the overall balance of produced energy, then its structure by individual sources is as follows: hydropower $-88.0 \%$; bioenergy $-10.5 \%$; wind energy $-1.5 \%$ [19].

The USA. In the first half of 2020 , the share of renewables in US electricity generation reached $22.2 \%$, overtaking coal for the first time $(16.9 \%)$. In the first half of 2019 , this ratio was in favor of coal: $19.9 \%$ (alternative sources) versus $23.6 \%$ (coal). They surpassed renewable sources and nuclear energy (20.5\%), with which in 2019 they were still on par.

By types of sources, the structure of renewable energy in 2020 was: wind $-9.1 \%$ of total electricity production in the United States (in $2019-7.7 \%, 2018-7.1 \%$ ); sun - 3.4\% (2019-2.7\%; $2018-2.3 \%$ ); hydropower $-7.8 \%$, other renewable sources (geothermal energy, timber, biomass waste, biofuel) $-1.9 \%$ [20].

Australia. The continent country has made significant progress for 2020. The share of renewable sources in total electricity generation has reached $25 \%$, steadily increasing in recent years $(21 \%$ in 2019; $19 \%$ in 2018). At the same time, the contribution of fossil fuels to electricity generation is annually decreasing (in particular, coal-fired generation decreased by a third in 2020 compared to $2019-33 \%$, and in 2019 (compared to 2018) the annual decrease was 20\%; for gas, these figures decreased, respectively: $4.2 \%$ and $20 \%$ ). In 2020, coal accounted for about $67 \%$ of generation and gas for $8 \%$.

Australia is still the only country where the lines "energy from accumulation systems" and "energy into accumulation systems" have appeared in the energy balance. Even though this value is only $0.03 \%$ of the energy balance, it is already beginning to play a tangible role in "softening" the fluctuations in energy production and consumption.

Alternative energy in Australia has achieved another significant result: the cost of "green" electricity (56.64 AUS / MWh) has become significantly cheaper than electricity produced from fossil fuels (coal-61.69, gas - 86.45).

The country's government is setting ambitious plans to bring the share of renewable energy to $50 \%$ by 2030 and to $94 \%$ - by 2040 [21].

China. After a pause in the development of renewable energy (2018-2019), China again began to increase its capacity. According to the State Committee for Development and Reforms of China, the share of renewable energy sources, including hydropower, reached $28.2 \%$ in 2020 , which is $0.3 \%$ higher than in the previous year. The share of renewable energy sources excluding hydroelectric power plants (mainly solar and wind energy) increased by $0.7 \%$ compared to 2019 and amounted to $10.8 \%$ [8]. At the same time, in ten provinces and regions, the production of electricity from renewable sources (excluding hydroelectric power plants) amounted to at least $30 \%$, and nine provinces and regions reached the level of $15 \%$ (ibid.).

Japan. There are a number of prerequisites in the country that, on the one hand, determine the adoption of measures to accelerate the development of renewable energy, on the other, they form a desire not to rush into this. The first group of prerequisites includes, first of all, the objective need to 
Leonid Hr. Melnyk, Oleksandr M. Derykolenko, Yuriy O. Mazin, Olena I. Matsenko, Vladyslav S. Piven. Modern Trends in the Development of Renewable Energy: the Experience of the EU and Leading Countries of the World

ensure the country's energy security in the face of an extreme shortage of energy resources and the desire to limit the production of atomic energy as much as possible after the Fukushima accident. This factor is reinforced by the desire to reduce the dependence of the country's economy on painful fluctuations in energy prices. Another prerequisite is conditioned by the need to combat global warming, especially since the basic document associated with this is called the "Kyoto Protocol". Finally, the development of renewable energy sources is a great niche, where Japan's powerful R\&D sector could make good money. Back in 2009, Japanese Prime Minister T. Aso proclaimed the goal of increasing the share of renewable energy sources in the country's energy balance from $8.4 \%$ in 2005 to $20 \%$ by 2020 (which correlates with the plans of the European Union countries).

Today in the country there are a number of motivational tools that stimulate the development of green energy. A system of subsidies for primary investments (purchase and installation of equipment), as well as the commercialization of "green" electricity (costs of entering the market, partial insurance of risks), is applied. Since 2010, a 50\% surcharge has been added to the current tax on fuel imports, the funds collected from which are spent for environmental purposes, including to stimulate the development of alternative energy. Besides, a targeted tax has been introduced ( $2 \%$ of the electricity tariff), the funds from which are directly spent on stimulating the development of new energy sources, and a "green tariff" has also been introduced for renewable energy sources [22].

At the same time, it should be noted that Japan, later than other advanced countries, introduced the "green tariff" widely used in the world. One of the reasons is the resistance of the largest fossilfueled electricity companies. In addition, the development of green energy was to some extent hindered by the Ministry of Economy, Trade, and Industry. It also oversees the energy sector and is not interested in increasing purchases of more expensive "green" energy (ibid.).

Nevertheless, significant capital investments in clean energy development are beginning to bear fruit. Between 2010 and 2019, Japan was the third-largest global investor (after China and the United States in renewable energy production, spending over USD 200 billion for this purpose).

Japan has practically achieved the task set. As of mid-2020, the share of renewable energy was $19 \%$, of which $8 \%$ is produced by solar power plants ( $45 \mathrm{GW}$ out of a total of $107 \mathrm{GW}$ of "green" energy). With outwardly quite moderate relative indicators of renewable energy production, the absolute values of the volumes of "green" energy are impressive. According to this indicator, Japan is in third place in the world (after China and the United States) [23].

A distinctive feature of Japan's green economy is the significant contribution of private home solar power plants located on the roofs of houses. It accounts for about a third of green energy production and $12 \%$ of the total energy balance in the country. In terms of this indicator, Japan is second only to Australia (24\%), Brazil (20\%), and Germany (15\%) [24].

Brazil. Renewable energy sources accounted for $46.1 \%$ in the total balance of energy resources used in the country in 2019, an increase from $45.5 \%$ compared to 2018.

In electricity production, the share of renewable resources has generally reached $84 \%$. The structure is as follows: $64 \%$ - hydropower, wind $-9 \%$, biomass $-9 \%$, sun $-2 \%$. At the same time, the production of the absolute amount of energy increases annually. So from 2018 to 2019, electricity generation by the sun increased by $92 \%$, and by the wind - by $155 \%$ [25].

The task is to increase the share of renewable resources in other areas of the energy complex: transport and utilities (heating and cooling of premises). In particular, in transport in 2020, programs are being implemented to increase the share of biofuels (bioethanol, biodiesel, and other biofuels) (ibid.).

According to the energy plan of the Brazilian Ministry of Energy, the share of wind farms is to increase to $28 \%$ by 2027 (excluding the share of hydropower), compared to $18 \%$ in 2020 . At the same time, the share of hydropower by 2027 should decrease to $50 \%$, which will contribute to the diversification of energy sources and reduce the problems that arise in hydropower in dry and dry years (ibid.). 
Л. Г. Мельник, О. М. Дериколенко, Ю. О. Мазін, О. І. Маценко, В. С. Півень.

Сучасні тренди розвитку відновлюваної енергетики: досвід ЄС та провідних країн світу

In 2020 , the capacity of solar power plants in the world increased by $14 \%$ to $142 \mathrm{GW}$ of newly installed capacity. If in 2010 there were only seven countries in the world with an installed capacity of more than $1 \mathrm{GW}$, then by the end of 2020 there are already 43 [26].

China is still the leader in solar energy, but its gap from other countries and regions has begun to shrink. If at the peak of $2017,50 \mathrm{GW}$ of solar power plants were installed in the country, then in 2020 this increase is much less. This is due to a sharp decline in government financial support for the development of solar energy. It has already become quite competitive for natural survival in the competitive struggle.

Other regions of the world continue to increase their solar capacity. In 2021, the US is expected to grow by $20 \%$. Europe almost doubled its capacity in 2019 and increased by another 5\% in 2020 over the previous year [26]. In fig. 1 shows the global production of solar (PV) energy.

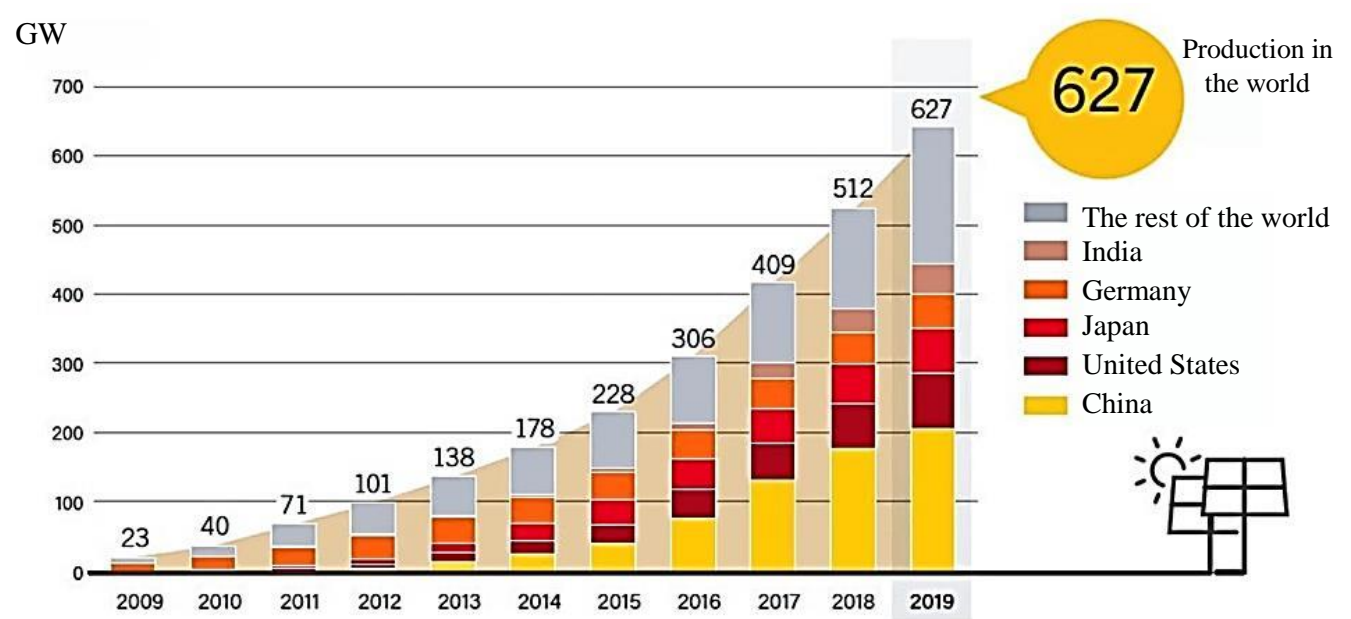

Fig. 1. Volumes of photo-solar energy produced in the world and by leading countries, 2009-2019 [27]

So we see 2020 as another double-digit year for solar energy. According to Edurno Zoko, director of clean technologies and renewable energy sources at IHS Markit, if the 2010s in solar energy were marked by the introduction of innovations, a significant reduction in unit costs, large government subsidies, then the 2020 s are likely to be characterized by strong development of renewable energy. energy already without state support, diversification of forms of energy production, and the number of producers, as well as the expansion of demand for solar power plants [26].

\section{Development of biogas energy}

The relevance of using biogas power plants lies in their multifunctionality. In addition to the possibility of obtaining thermal or electrical energy, they allow you to solve a number of related problems. In particular, it prevents the pollution of the atmosphere by greenhouse gases generated by rotting organic matter; degassed and decontaminated organic matter can be 
Leonid Hr. Melnyk, Oleksandr M. Derykolenko, Yuriy O. Mazin, Olena I. Matsenko, Vladyslav S. Piven. Modern Trends in the Development of Renewable Energy: the Experience of the EU and Leading Countries of the World

returned to enrich the soil; degassing of landfills and sewers prevents possible cases of their spontaneous combustion.

The raw materials for biogas plants can be plant residues (for example, corn, processed seeds, etc.); animal manure, wood waste, food and food industry waste, household waste, wastewater. Only those species that do not compete with food for agricultural land are counted here.

Figures 2 and 3 show the volumes of biogas produced in the world in 2018 and the dynamics of the capacities of biogas plants in the leading countries of the world.

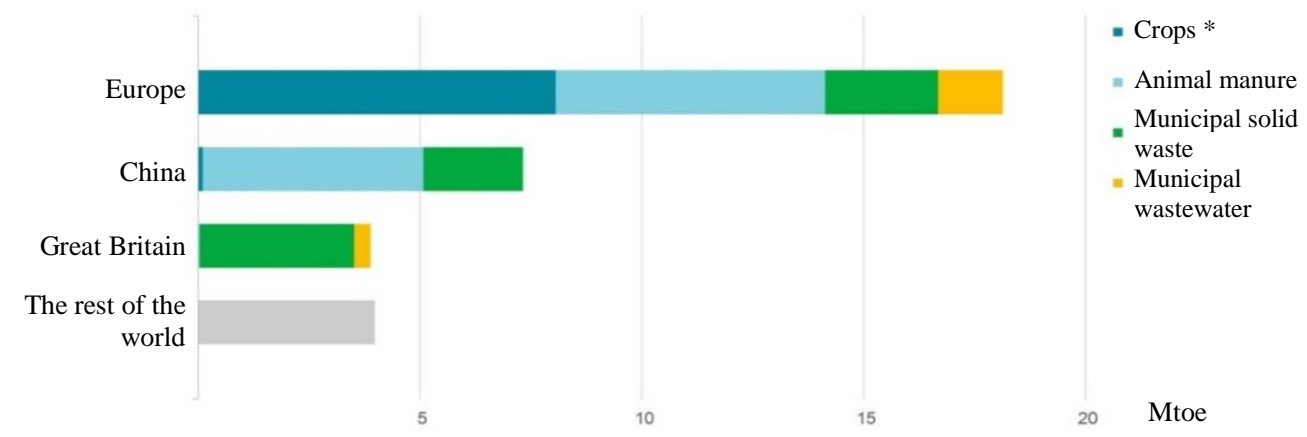

* Crops include energy crops, crop residues and sequential crops. Note: 1 Mtoe $=11.63$ terawatt-hours $(\mathrm{TWh})=41.9$ petajoules $(\mathrm{PJ})$.

Fig. 2. Biogas: the largest producers by resource type in 2018 [28]

Biogas consumption by end use,

$$
2018
$$
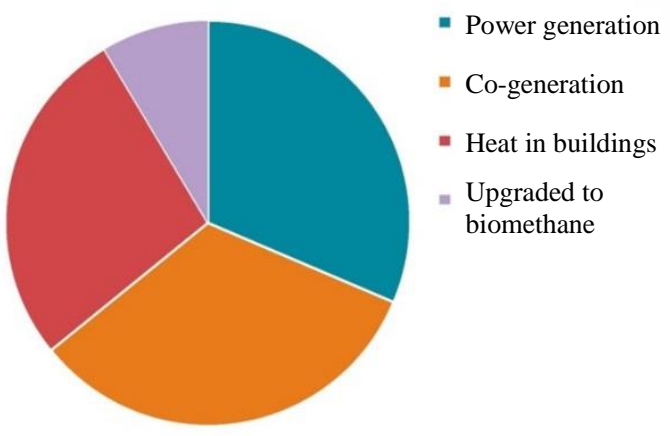

Biogas installed power generation capacity,

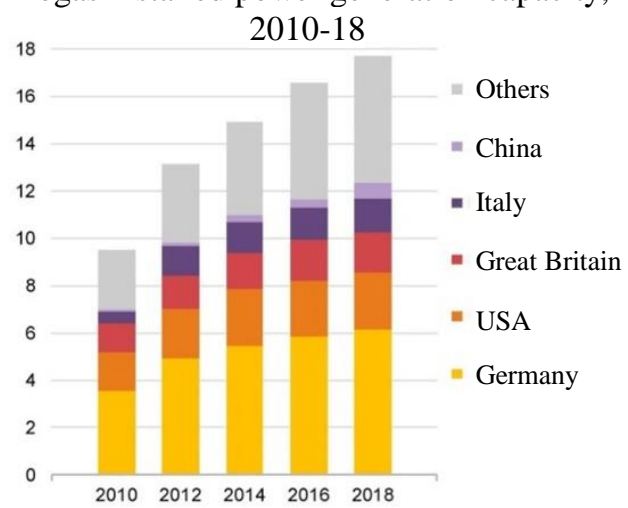

Note: GW = gigawatt.

Fig. 3. Main producers and consumers of biogas [28]

Biogas and biomethane production in 2018 amounted to about 35 million tonnes of oil equivalent (MTE). This is only a small part of its potential. The full use of biogas feedstock, according to experts, could cover about $20 \%$ of today's global gas demand [29].

Today, the maximum number of biogas plants - about 15 million - operates in China. India has about 10 million installations. The biogas industry is actively developing in Europe. 
Л. Г. Мельник, О. М. Дериколенко, Ю. О. Мазін, О. І. Маценко, В. С. Півень.

Сучасні тренди розвитку відновлюваної енергетики: досвід ЄС та провідних країн світу

In European practice, $75 \%$ of biogas is produced from agricultural waste, $17 \%$ from organic waste from private households and enterprises, and another $8 \%$ from sewage treatment plants [24].

Today the first place in Europe in terms of the number of operating biogas plants belongs to Germany - in 2016 there were about 10.800 of them. Only 7\% of the biogas produced by these enterprises go into gas pipelines, the rest is used for the needs of the manufacturer. In the future, 10 $20 \%$ of the natural gas used in the country can be replaced by biogas. In terms of the scale of use of biogas, Denmark is in the lead: this type of fuel provides almost $20 \%$ of the country's energy consumption.

According to the European Biogas Association, the leaders in the number of biogas plants, apart from Germany, are Italy - 1491, Great Britain - 813, France - 736, Switzerland - 633, Czech Republic - 554, Austria - 436 plants [30].

The biogas market in the USA is developing much more slowly than in Europe. For example, despite the presence of a large number of farms, only about 200 biogas plants are operating on agricultural waste on the territory of the country [24].

\section{Strategic directions in the development of renewable energy}

A separate page in the formation of alternative energy is the rivalry of two directions of its development, based on the creation of concentrated and deconcentrated (distributed) power plants.

The first focuses on the concentration of production energy units (solar panels or wind turbines) in one area. In this case, not only territorial but also subjective concentration occurs. In other words, production capacities are concentrated in the hands of one, even if collective, the owner (legal entity). In this direction are countries with a sufficient area of free territories. For solar energy, these are usually desert territories (China, India, Australia, African countries, the United States), for wind power - a coastal sea zone (Japan, Great Britain, the Netherlands, Germany). Tables 2 and 3 show the world's largest solar power plants and wind farms.

Table 2

The world's largest solar power plants [31]

\begin{tabular}{|l|r|}
\hline \multicolumn{1}{|c|}{ SPP name } & Power, MW \\
\hline Tengger Desert Solar Park, China & 1547 \\
\hline Sweihan Photovoltaic Independent Power Project, UAE & 1177 \\
\hline Yanchi Ningxia Solar Park, China & 1000 \\
\hline Datong Solar Power Top Runner Base, China & 1070 \\
\hline Kurnool Ultra Mega Solar Park, India & 1000 \\
\hline Longyangxia Dam Solar Park, China & 850 \\
\hline Enel Villanueva PV Plant, Mexico & 828 \\
\hline Kamuthi Solar Power Station, India & 648 \\
\hline Solar Star Projects, USA & 579 \\
\hline Topaz Solar Farm / Desert Sunlight Solar Farm, USA & 550 \\
\hline
\end{tabular}

The second direction is associated with the deconcentration of energy sources, that is, the dispersal of individual capacities both across the territory and by forms of ownership. For example, individual panels or wind turbines may be owned by different homeowners. The concentration of the produced energy occurs already at the final stage due to the creation of a unified energy system (EnerNet), which will solve all the economic and technical problems of energy production and consumption. Most European countries and Japan follow this path. 
Leonid Hr. Melnyk, Oleksandr M. Derykolenko, Yuriy O. Mazin,

Olena I. Matsenko, Vladyslav S. Piven. Modern Trends in the Development of Renewable Energy: the Experience of the EU and Leading Countries of the World

The world's largest wind farms [32]

Table 3

\begin{tabular}{|l|r|}
\hline \multicolumn{1}{|c|}{ Wind farm name } & Power, MW \\
\hline \multicolumn{1}{|c|}{$\mathbf{1}$} & $\mathbf{2}$ \\
\hline Jiuquan Wind Power Base, China & 2000 \\
\hline Jaisalmer Wind Park, India & 1600 \\
\hline Alta Wind Energy Center, USA & 1548 \\
\hline Muppandal Wind Farm, India & 845 \\
\hline Shepherds Flat Wind Farm, USA & 782 \\
\hline Roscoe Wind Farm, USA & 736 \\
\hline Horse Hollow Wind Energy Center, Texas, USA & 662 \\
\hline Capricorn Ridge Wind Farm, Texas, USA & 650 \\
\hline Walney Extension Offshore Wind Farm, Great Britain & 630 \\
\hline London Array Offshore Wind Farm, Great Britain & M \\
\hline
\end{tabular}

The largest Ukrainian wind farm is Botievo Wind Farm (200 MW).

Conclusions and prospects of further research. The transition to renewable energy sources is critical for most countries. This is one of the most important steps towards ensuring their energy independence and further restructuring of economic systems towards the formation of a "green" economy. It is gratifying that, along with other countries, Ukraine is making its efforts in this.

\section{References}

1. Rifkin, J. (2015). Zero Marginal Cost Society: The Internet of Things, the Collaborative Commons, and the Eclipse of Capitalism. New York: St. Martin's Griffin Publisher, 448 p.

2. Renewable energy highlights. International Renewable Energy Agency. Retrieved from https://www.irena.org/-

/media/Files/IRENA/Agency/Publication/2020/Ju1/Renewable_energy_highlights_July_2020.pdf?la $=$ en $\&$ hash=75B114DB7A55F4260F41F64C4DFF793DB2044306.

3. Renewables 2020. Global Status Report a Comprehensive Annual Overview of The State of Renewable Energy. REN21. Retrieved from https://www.ren21.net/gsr-2020/.

4. New energy outlook 2017 (2016). Annual long-term economic forecast. Bloomberg New Energy Finance. Retrieved from https://about.bnef.com/new-energy-outlook/.

5. Shahan, Z. (2016). 10 Solar Energy Facts \& Charts You (\& Everyone) should know. Clean Technica. Retrieved from https://cleantechnica.com/2016/08/17/10-solar-energy-facts-chartseveryone-know/.

6. Weaver, J. F. (2016). Solar power cost down $25 \%$ in five months - "There's no reason why the cost of solar will ever increase again". Electrek. Retrieved from https://electrek.co/2016/09/26/solarpower-cost-down-25-in-five-months-theres-no-reason-why-the-cost-of-solar-will-ever-increaseagain/.

7. Energy in Sweden. Wikipedia. Retrieved from https://en.wikipedia.org/wiki/Energy_in_Sweden.

8. Kitaj ustanovil czeli razvitiya VIE na tekushhij god [China sets renewable energy targets for the current year]. Elektrovesti.net. Retrieved from https://elektrovesti.net/71238_kitay-ustanovil-tselirazvitiya-vie-na-tekushchiy-god [In Russian].

9. Global Electricity Review. EMBER. Retrieved from https://ember-climate.org/wpcontent/uploads/2020/03/Ember-2020GlobalElectricityReview-PrintA4.pdf.

10. Jones, D., Graham, E., Tunbridge, P. Wind And Solar Now Generate One-Tenth Of Global Electricity. Global half-year electricity analysis. EMBER. Retrieved from https://emberclimate.org/project/global-electricity-h12020/. 
Л. Г. Мельник, О. М. Дериколенко, Ю. О. Мазін, О. І. Маценко, В. С. Півень.

Сучасні тренди розвитку відновлюваної енергетики: досвід ЄС та провідних країн світу

11. Calma, J. Wind and solar energy is steadily replacing coal. The verge. Retrieved from https://www.theverge.com/2020/8/13/21366373/wind-solar-power-electricity-doubled-paris-climatechange-agreement.

12. King, J. Could renewables become the top UK power source of 2020 ? Renewable energy world. Retrieved from https://www.renewableenergyworld.com/2020/08/24/could-renewables-become-thetop-uk-power-source-of-2020/\#gref.

13. Waldholz, R. Germany marks first ever quarter with more than 50 pct renewable electricity. Clean energy wire. Retrieved from https://www.cleanenergywire.org/news/germany-marks-first-everquarter-more-50-pct-renewable-electricity.

14. Cockburn, H. Climate crisis: Renewable energy provided almost half of UK's electricity in first three months of 2020. Independent. Retrieved from https://www.independent.co.uk/author/harry-cockburn.

15. Sarah, G. Renewables accounted for record $47 \%$ of UK generation in first quarter of 2020. Edie Retrieved from https://www.edie.net/news/10/Renewables-accounted-for-record-47--of-UKgeneration-in-first-quarter-of-2020/.

16. Renewables supply $51 \%$ of electricity in 2019. The Portugal News. 07.02.2020. Retrieved from https://www.theportugalnews.com/news/renewables-supply-51-of-electricity-in-2019/52939.

17. Swiss electricity getting cleaner, says energy report. SWI - swissinfo. Retrieved from https://www.swissinfo.ch/eng/renewables-drive_swiss-electricity-getting-cleaner--says-energyreport/44001606.

18. Austria 2020. Energy Policy Review. IEA. Retrieved from https://www.iea.org/reports/austria-2020.

19. Norway - 2018 update (2018). Bioenergy policies and status of implementation. Country Reports. IEA Bioenergy. Retrieved from https://www.ieabioenergy.com/wpcontent/uploads/2018/10/CountryReport2018_Norway_final.pdf.

20. Shahan, Z. Renewable Energy $=22.2 \%$ of US Electricity in 1st Half of 2020 (Charts). CleanTechnica. Retrieved from https://cleantechnica.com/2020/09/12/renewable-energy-22-2-of-uselectricity-in-1st-half-of-2020-charts/.

21. Vorrath, S. Milestone: Australia's main grid reaches 25 pct renewables over last year. Clean Energy News and Analysis. Retrieved from https://reneweconomy.com.au/milestone-australias-main-gridreaches-25-pct-renewables-over-last-year-32967/.

22. Strel'czov, D. V. (2011) "Chistaya" energetika v Yaponii [Clean energy in Japan]. Vostochnaya analitika - Eastern analytics. Retrieved from https://cyberleninka.ru/article/n/chistaya-energetika-vyaponii/viewer [In Russian].

23. Hall, M. Japan's struggle to drive down renewable cost. $P V$ magazine international. Retrieved from https://www.pv-magazine.com/2020/08/20/japans-struggle-to-drive-down-renewables-costs/.

24. Obzor proizvodstva biogaza v mire [Overview of biogas production in the world]. Biowatt. Retrieved from http://www.biowatt.com.ua/analitika/obzor-proizvodstva-biogaza-v-mire/ [In Russian].

25. Renewables gained ground in Brazil in 2019. Hydro Review. Retrieved from https://www.hydroreview.com/2020/07/27/renewables-gained-ground-in-brazil-in-2019/\#gref.

26. IHS Markit: mirovoj prirost moshhnosti solnechny`kh e`lektrostanczij v 2020 godu dostignet 147 GVt [IHS Markit: global growth in solar power capacity in 2020 will reach $147 \mathrm{GW}$ ] elektrovesti.net. Retrieved from https://elektrovesti.net/69072_ihs-markit-mirovoy-prirostmoshchnosti-solnechnykh-elektrostantsiy-v-2020-godu-dostignet-142-gvt.

27. Hunt, T. The solar singularity: 2020 update (part 1). Greentech Media. Retrieved from https://www.greentechmedia.com/articles/read/the-solar-singularity-2020-update-part-1.

28. Outlook for biogas and biomethane. Prospects for organic growth (2020). World Energy Outlook special Report. IEA. Retrieved from https://www.iea.org/reports/outlook-for-biogas-and-biomethaneprospects-for-organic-growth.

29. Korobkova, E. Biogaz i neispol zovannyj potenczial biometana po vsemu miru [Biogas and untapped biomethane potential around the world]. ENERGO-SMI - ENERGO-MEDIA. Retrieved from https://energosmi.ru/archives/43412 [In Russian].

30. Kak poluchit` elektrichestvo iz kurinogo pometa [How to get electricity from chicken droppings]. Gazeta o lichnostyakh i liczedeyakh "Licza". Novosti. E'kologiya-Newspaper about personalities 
Leonid Hr. Melnyk, Oleksandr M. Derykolenko, Yuriy O. Mazin, Olena I. Matsenko, Vladyslav S. Piven. Modern Trends in the Development of Renewable Energy: the Experience of the EU and Leading Countries of the World

and actors "Faces". News. Ecology. Retrieved from http://www.litsa.com.ua/show/a/34848 [In Russian].

31. The world's biggest solar power plants. PowerTechnology. Retrieved from https://www.powertechnology.com/features/the-worlds-biggest-solar-power-plants/.

32. Top 10 biggest wind farms. PowerTechnology. Retrieved from https://www.powertechnology.com/features/feature-biggest-wind-farms-in-the-world-texas/.

Manuscript received 28 May 2020

\section{Современные тренды в развитии возобновляемой энергетики:} опыт ЕС и ведущих стран мира

\section{ЛЕОНИД ГРИГОРЬЕВИч МЕЛЬНИК*, АЛЕКСАНДР НИКОЛАЕВИч ДЕРИКОЛЕНКо *, Юрий АЛЕКСАНДРОВИч МАЗИН ЕЛЕНА ИГОРЕВНА МАЦЕНКО ВЛАДИСЛАВ СЕРГЕЕВИЧ ПИВЕНЬ}

*доктор экономических наук, профессор, профессор кафедры экономики, предпринимательства и бизнес-администрирования Сумского государственного университета, директор Научно-исследовательского института экономики развития МОН Украины и НАН

Украины в составе Сумского государственного университета, ул. Р.-Корсакова, 2, г. Сумы, 40007, Украина,

тел.: 00-380-542-332223, e-mail: melnyk@econ.sumdu.edu.ua

** доктор экономических наук, дочент, доиент кафедры экономики, предпринимательства и

бизнес-администрирования Сумского государственного университета,

ул. Р.-Корсакова, 2, г. Сумы, 40007, Украина,

тел.:00-380-542-332223, e-mail: o.derykolenko@econ.sumdu.edu.ua

****кандидат экономических наук, дочент, доцент кафедры экономики, предпринимательства и бизнес-администрирования Сумского государственного университета, ул. Р.-Корсакова, 2, г. Сумыл, 40007, Украина,

тел.: 00-380-542-332223, e-mail: y.mazin@econ.sumdu.edu.ua

\footnotetext{
**** техник 1-й категории научно-исследовательской части кафедры экономики, предпринимательства и бизнес-администрирования Сумского государственного университета, ул. Р.-Корсакова, 2, г. Сумы, 40007, Украина,

тел.:00-380-542-332223,e-mail: ol.matsenko@econ.sumdu.edu.ua

***** студент Научно-исследовательского института финансов, экономики и управления имени Олега Балацкого Сумского государственного университета, ул. Р.-Корсакова, 2, г. Сумыл, 40007, Украина, тел.: 00-380-542-332223, e-mail: vladislavpiven2002@gmail.com
}

Одним из ключевых моментов в сестейновом развитии является энергетическая безопасность и независимость. В современных условиях стремительного ростра и развития технологий всё больше внимания уделяется поискам практических решений экологически безопасного и недорогого производства энергии. Вопросами развития и использования альтернативных источников энергии уже длительное время занимаются ученые разных сфер научной деятельности во всем мире. Доля возобновляемых источников энергии в генерации электроэнергии во всём мире неуклонно растёт, что свидетельствует о расширении использования энергии, получаемой из альтернативных источников, таких как, например, ветер и 
Л. Г. Мельник, О. М. Дериколенко, Ю. О. Мазін, О. І. Маценко, В. С. Півень.

Сучасні тренди розвитку відновлюваної енергетики: досвід ЄС та провідних країн світу

солнце. Данные тенденции свидетельствуют о стремлении потребителей максимально отказаться от использования ископаемых источников энергии и атомных станций с целью обеспечения дальнейшего сестейнового развития. В сложившихся условиях пандемии COVID-19 спрос на электроэнергию во всем мире снизился, однако, как показывает исследование, на развитие возобновляемой энергетики данная пандемия не повлияла. В статье проведён анализ современных трендов в развитии возобновляемой энергетики с учетом уже полученного опыта стран ЕС и ведущих стран мира в данной сфере. В результате были сделаны выводы о том, что в современных условиях для достижения сестейнового развития необходимы трансформационные процессы в такой важной сфере, как энергетика. Мощным толчком для подобных изменений послужили разные процессы в мировой экономике, которые способствовали интенсивному развитию альтернативных источников энергии. Многие страны добились существенных результатов в развитии возобновляемой энергетики.

Ключевые слова: тренд, возобновляемые источники энергии, электроэнергия, развитие, возобновляемая энергетика, альтернативная энергетика, энергетическая безопасность.

\author{
Mechanism of Economic Regulation, 2020, No 3, 117-133 \\ ISSN 1726-8699 (print)
}

Сучасні тренди розвитку відновлюваної енергетики: досвід ЄС та провідних країн світу

$$
\begin{aligned}
& \text { ЛЕОНІД ГРИГОРОвИч МЕЛЬНИК*, } \\
& \text { ОЛЕКСАНДР МИКОЛАЙОВИЧ ДЕРИКОЛЕНКО**, } \\
& \text { ЮРІй ОЛЕКСАНДРОВИЧ МАЗІН }{ }^{* * *} \text {, } \\
& \text { ОЛЕНА ІГОРІВНА МАЦЕНКо }{ }^{* * * *} \text {, } \\
& \text { ВЛАДИСЛАВ СЕРГГЙОВИч ПІВЕНЬ }{ }^{* * * * *}
\end{aligned}
$$

*дктор економічних наук, професор, професор кафедри економіки, підприємництва та бізнесадміністрування Сумського державного університету,

директор Науково-дослідного інституту економіки розвитку МОН Украӥни та НАН Украӥни у складі Сумського державного університету

вул. Р.-Корсакова, 2, м. Суми, 40007, Украӥна,

тел.: 00-380-542-332223, e-mail: melnyk@econ.sumdu.edu.ua

**октор економічних наук, доцент кафедри економіки, підприємництва та бізнес-

адміністрування Сумського державного університету,

вул. Р.-Корсакова, 2, м. Суми, 40007, Украӥна,

тел.: 00-380-542-332223, e-mail: o.derykolenko@econ.sumdu.edu.ua

${ }^{* * *}{ }^{\kappa}$ кандидат економічних наук, доиент, доцент кафедри економіки, підприсмництва та бізнесадміністрування Сумського державного університету, вул. Р.-Корсакова, 2, м. Суми, 40007, Україна,

тел.: 00-380-542-332223, e-mail:y.mazin@econ.sumdu.edu.ua

*****технік 1-ї категорії науково-дослідної частини кафедри економіки, підприємництва та бізнесадміністрування Сумського державного університету,

вул. Р.-Корсакова, 2, м. Суми, 40007, Україна,

тел.: 00-380-542-332223, e-mail: ol.matsenko@econ.sumdu.edu.ua

****** студент навчально-наукового інституту фінансів, економіки та менеджменту імені Олега Балачького Сумського державного університету,

вул. Р.-Корсакова, 2, м. Суми, 40007, Україна,

тел.: 00-380-542-332223, e-mail: vladislavpiven2002@gmail.com 
Leonid Hr. Melnyk, Oleksandr M. Derykolenko, Yuriy O. Mazin, Olena I. Matsenko, Vladyslav S. Piven. Modern Trends in the Development of Renewable Energy: the Experience of the EU and Leading Countries of the World

Одним з ключових моментів сестейнового розвитку є енергетична безпека і незалежність. У сучасних умовах стрімкого ростра і розвитку технологій все більше уваги приділяється пошукам практичних рішень екологічно безпечного і недорогого виробництва енергії. Питаннями розвитку і використання альтернативних джерел енергії вже тривалий час займаються вчені різних сфер наукової діяльності в усьому світі. Частка відновлюваних джерел енергії в генерації електроенергії в усьому світі неухильно зростає, що свідчить про розширення використання енергії, одержуваної з альтернативних джерел, таких як, наприклад, вітер і сонце. Дані тенденції свідчать про прагнення споживачів максимально відмовитися від використання викопних джерел енергії і атомних станцій 3 метою забезпечення подальшого сестейнового розвитку. У сформованих умовах пандемії COVID-19 попит на електроенергію в усьому світі знизився, однак, як показує дослідження, на розвиток відновлюваної енергетики дана пандемія не вплинуло. У статті проведений аналіз сучасних трендів у розвитку відновлюваної енергетики 3 урахуванням вже отриманого досвіду країн СС і провідних країн світу в цій сфері. В результаті були зроблені висновки про те, що в сучасних умовах для досягнення сестейнового розвитку необхідні трансформаційні процеси в такій важливій сфері, як енергетика. Потужним поштовхом для подібних змін послужили різні процеси в світовій економіці, які сприяли інтенсивному розвитку альтернативних джерел енергії. Багато країн добилися істотних успіхів у розвитку відновлюваної енергетики.

Ключові слова: тренд, поновлювані джерела енергії, електроенергія, розвиток, відновлювальна енергетика, альтернативна енергетика, енергетична безпека

JEL Codes: $\mathrm{Q} 40$

Tables: 3; Figures: 3; References: 32

Language of the article: English

תimepamypa

1. Rifkin, J. Zero Marginal Cost Society: The Internet of Things, the Collaborative Commons, and the Eclipse of Capitalism / J. Rifkin. - New York : St. Martin's Griffin Publisher, 2015. - 448 c.

2. Renewable energy highlights [Електронний ресурс] / International Renewable Energy Agency. Режим доступу : https://www.irena.org/-/media/Files/IRENA/Agency/Publication/2020/Jul/ Renewable_energy_highlights_July_2020.pdf?la=en\&hash=75B114DB7A55F4260F41F64C4DFF7 93DB2044306 (дата звернення: 20.09.2020).

3. Renewables 2020. Global Status Report a Comprehensive Annual Overview of The State of Renewable Energy [Електронний ресурс] / REN21. - Режим доступу : https://www.ren21.net/gsr2020.

4. New energy outlook 2017. Annual long-term economic forecast [Електронний pecypc] / Bloomberg New Energy Finance. - Режим доступу : https://about.bnef.com/new-energy-outlook/.

5. Shahan, Z. 10 Solar Energy Facts \& Charts You (\& Everyone) should know [Електронний ресурс]/ Z. Shahan // Clean Technica. - Режим доступу : https://cleantechnica.com/2016/08/17/10-solarenergy-facts-charts-everyone-know/.

6. Weaver, J. F. Solar power cost down $25 \%$ in five months - «There's no reason why the cost of solar will ever increase again» [Електронний ресурс] / J. F. Weaver // Electrek. - Режим доступу : https://electrek.co/2016/09/26/solar-power-cost-down-25-in-five-months-theres-no-reason-why-thecost-of-solar-will-ever-increase-again/.

7. Energy in Sweden [Електронний pecypc] / Wikipedia. - Режим доступу : https://en.wikipedia.org/wiki/Energy_in_Sweden.

8. Китай установил цели развития ВИЭ на текущий год [Електронний ресурс] / Elektrovesti.net. - Режим доступу : https://elektrovesti.net/71238_kitay-ustanovil-tseli-razvitiya-vie-na-tekushchiygod.

9. Global Electricity Review [Електронний ресурс] / EMBER. - Режим доступу : https://emberclimate.org/wp-content/uploads/2020/03/Ember-2020GlobalElectricityReview-PrintA4.pdf. 
Л. Г. Мельник, О. М. Дериколенко, Ю. О. Мазін, О. І. Маценко, В. С. Півень.

Сучасні тренди розвитку відновлюваної енергетики: досвід ЄС та провідних країн світу

10. Jones, D. Wind And Solar Now Generate One-Tenth Of Global Electricity. Global half-year electricity analysis [Електронний ресурc] / D. Jones, E. Graham, P. Tunbridge // EMBER. - Режим доступу : https://ember-climate.org/project/global-electricity-h12020/.

11. Calma, J. Wind and solar energy is steadily replacing coal [Електронний pecypc] / J. Calma // The verge. - Режим доступу : https://www.theverge.com/2020/8/13/21366373/wind-solar-powerelectricity-doubled-paris-climate-change-agreement.

12. King, J. Could renewables become the top UK power source of 2020? [Електронний ресурс] / J. King // Renewable energy world. - Режим доступу : https://www.renewableenergyworld.com/2020/08/24/could-renewables-become-the-top-uk-powersource-of-2020/\#gref.

13. Waldholz, R. Germany marks first ever quarter with more than 50 pct renewable electricity [Електронний pecypc] / R. Waldholz // Clean energy wire. - Режим доступу : https://www.cleanenergywire.org/news/germany-marks-first-ever-quarter-more-50-pct-renewableelectricity.

14. Cockburn, $H$. Climate crisis: Renewable energy provided almost half of UK's electricity in first three months of 2020 [Електронний ресурс] / H. Cockburn // Independent. - Режим доступу : https://www.independent.co.uk/author/harry-cockburn.

15. Sarah, G. Renewables accounted for record 47\% of UK generation in first quarter of 2020. [Електронний pecypc] / G. Sarah // Edie. - Режим доступу : https://www.edie.net/news/10/Renewables-accounted-for-record-47--of-UK-generation-in-firstquarter-of-2020\%.

16. Renewables supply 51\% of electricity in 2019 [Електронний ресурс] / The Portugal News. - Режим доступу : https://www.theportugalnews.com/news/renewables-supply-51-of-electricity-in$2019 / 52939$.

17. Swiss electricity getting cleaner, says energy report [Електронний ресурc] / SWI - swissinfo. Режим доступу : https://www.swissinfo.ch/eng/renewables-drive_swiss-electricity-getting-cleaner-says-energy-report/44001606

18. Austria 2020. Energy Policy Review [Електронний ресурс] / IEA. - Режим доступу : https://www.iea.org/reports/austria-2020.

19. Norway - 2018 update. Bioenergy policies and status of implementation. Country Reports. [Електронний ресурс] / IEA Bioenergy. - Режим доступу : https://www.ieabioenergy.com/wpcontent/uploads/2018/10/CountryReport2018_Norway_final.pdf.

20. Shahan, Z. Renewable Energy $=22.2 \%$ of US Electricity in 1st Half of 2020 (Charts) [Електронний pecypc] / Z.Shahan // CleanTechnica. - Режим доступу https://cleantechnica.com/2020/09/12/renewable-energy-22-2-of-us-electricity-in-1st-half-of-2020charts/.

21. Vorrath, $S$. Milestone: Australia's main grid reaches 25 pct renewables over last year [Електронний pecypc] / S. Vorrath // Clean Energy News and Analysis. - Режим доступу : https://reneweconomy.com.au/milestone-australias-main-grid-reaches-25-pct-renewables-over-lastyear-32967/.

22. Стрельцов, Д. В. «Чистая» энергетика в Японии [Електронний ресурс] / Д. В. Стрельцов // Востояная аналитика. - Режим доступу : https://cyberleninka.ru/article/n/chistaya-energetika-vyaponii/viewer.

23. Hall, M. Japan's struggle to drive down renewable cost [Електронний pecypc] / M. Hall // PV magazine international. - Режим доступу : https://www.pv-magazine.com/2020/08/20/japansstruggle-to-drive-down-renewables-costs/.

24. Обзор производства биогаза в мире [Електронний ресурс] / Biowatt. - Режим доступу : http://www.biowatt.com.ua/analitika/obzor-proizvodstva-biogaza-v-mire/.

25. Renewables gained ground in Brazil in 2019 [Електронний ресурс] / Hydro Review. - Режим доступу : https://www.hydroreview.com/2020/07/27/renewables-gained-ground-in-brazil-in2019/\#gref. 
Leonid Hr. Melnyk, Oleksandr M. Derykolenko, Yuriy O. Mazin, Olena I. Matsenko, Vladyslav S. Piven. Modern Trends in the Development of Renewable Energy: the Experience of the EU and Leading Countries of the World

26. IHS Markit: мировой прирост мощности солнечных электростанций в 2020 году достигнет 147 ГВт [Електронний ресурс] / Новости elektrovesti.net. - Режим доступу : https://elektrovesti.net/69072_ihs-markit-mirovoy-prirost-moshchnosti-solnechnykh-elektrostantsiyv-2020-godu-dostignet-142-gvt.

27. Hunt, T. The solar singularity: 2020 update (part 1) [Електронний pecypc] / T. Hunt // Greentech Media. - Режим доступу : https://www.greentechmedia.com/articles/read/the-solar-singularity2020-update-part-1.

28. Outlook for biogas and biomethane. Prospects for organic growth. World Energy Outlook special Report [Електронний ресурс] / IEA. - Режим доступу : https://www.iea.org/reports/outlook-forbiogas-and-biomethane-prospects-for-organic-growth.

29. Коробкова, Е. Биогаз и неиспользованный потенциал биометана по всему миру [Електронний pесурс] / Е. Коробкова // ЭНЕРГО-СМИ. - Режим доступу : https://energosmi.ru/archives/43412.

30. Как получить электричество из куриного помета [Електронний ресурс] / Газета о личностях и лицедеях «Лица». Новости. Экология. - Режим доступу : http://www.litsa.com.ua/show/a/34848.

31. The world's biggest solar power plants [Електронний pecypc] / PowerTechnology. - Режим доступу : https://www.power-technology.com/features/the-worlds-biggest-solar-power-plants/.

32. Top 10 biggest wind farms [Електронний pecypc] / PowerTechnology. - Режим доступу : https://www.power-technology.com/features/feature-biggest-wind-farms-in-the-world-texas/. 